\title{
Abundance of Hetrocystous Blue Green Algae of Rice Field of Mangaldoi Sub Division, Darrang District Assam
}

\author{
Matiur Rahman, Milu Rani Das and Ranee Das \\ Department of Botany, University of Science and Technology, Meghalaya
}

\section{ABSTRACT}

An Experiment were conducted from Feb 2017 to Jan. 2019 in Mangaldoi sub division, Darrang District Assam for taxonomical study of blue green algae In these studies total 67 numbers of heterocystous blue green algal species were identified belonged to the genus. Richelia, Cylindrospermum, Anabaena,. Nostoc, Aulosira, Camptylonemopsis Scytonema, Tolypothrix, Microchaete, Fortiea, Calothrix, Dichothrix, Rivularia, Gloeotrichia, Stigonema. Fischerella, Westiellops, Hapalosiphon. Out of which the Genus Nostoc having highest number of species, and Order Nostocales consists $91.04 \%$ of species

KEY WORDS: ABUNDANCE, BLUE GREEN ALGAE, HETEROCYSTOUS, RICE FIELD, GENUS NOSTOC.

\section{INTRODUCTION}

Blue green algae, constitute a fascinating group of prokaryotic photosynthetic organisms, some of them fix atmospheric nitrogen , mostly heterocystous types by which they can increase fertility in the tropical rice field. Many workers have studied the cyanobacterial flora of rice fields of our country.( Rai and Bergman, 2002; Jaiswal et al.,2008; Karthikeyan et al.,2009, Anamika Singh , Hema Joshi 2018,) cyanobacteria have enormous potential in serving humanity in many ways as bio-fertilizer, protein source, food and fodder etc. It maintain ecological balence and conservation of soil also. Their diazotrophic nature, wide distribution pattern and capability to enter into N2 -fixing symbiosis make them attractive research interest. Cyanobacteria have a long history of usage in agriculture as biofertilizer (Whitton, 2000). They improve the texture of soil and increase the biochemical quality of the soil which forms a rapidly multiplying over of microscopic plants. They have highly colonization with almost all types of soils. (Bold and Wanne, 1978) These strains are having special concern in microbiology as

Biosc Biotech Res Comm P-ISSN: 0974-6455 E-ISSN: 2321-4007

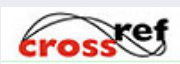

Identifiers and Pagination

Year: 2021 Vol: 14 No (5) Special Issue

Pages: 242-244

This is an open access article under Creative

Commons License Attribn 4.0 Intl (CC-BY). DOI: http://dx.doi.org/10.21786/bbrc/14.5/43 they are widely used as biofertilizer. Keeping in view in a study were conducted to find out the heterocystous types of blue green algae with special interest.

\section{MATERIAL AND METHODS}

Water samples were collected from seven different sites of Mangaldoi sub-division of Darrang District, Assam. To perform the proposed taxonomical study in a precise manner, the Mangaldoi Sub-division is specified into seven selected sites for the present study. During the field survey, specimens are being collected in wide mounted bottles, test tubes, polythene bags, plankton net, scalpel, blade, forceps are being used to collect blue green algae from running water. Sampling bottle is filled up with specimen along with water collected from the area to its one third capacities, the remaining parts is for aeration. Species of different levels of water is being collected by using pipes \&t tubes. Samples will be collected from the same area in each case. The methods and techniques are used on the basis of "Standard Operating Procedures for the Collection and Analysis of Aquatic Algae"June 2016 (Version2.0) Published by North Carolina department of Environmental Quality. 2016.

\section{RESULTS AND DISCUSSION}

Identification of collected species was carried out by consulting keys given by, Fritch (1935) Smith (1950),
Article Information

Received: $15^{\text {th }}$ Jan 2021

ccepted after revision: $30^{\text {th }}$ Mar 2021 
Desikachary,(1959) Randhawa, (1959), and some published literature, monographs of algal taxonomy also studied. However Desikachary's (1959) classification is followed in arranging the genera and species.

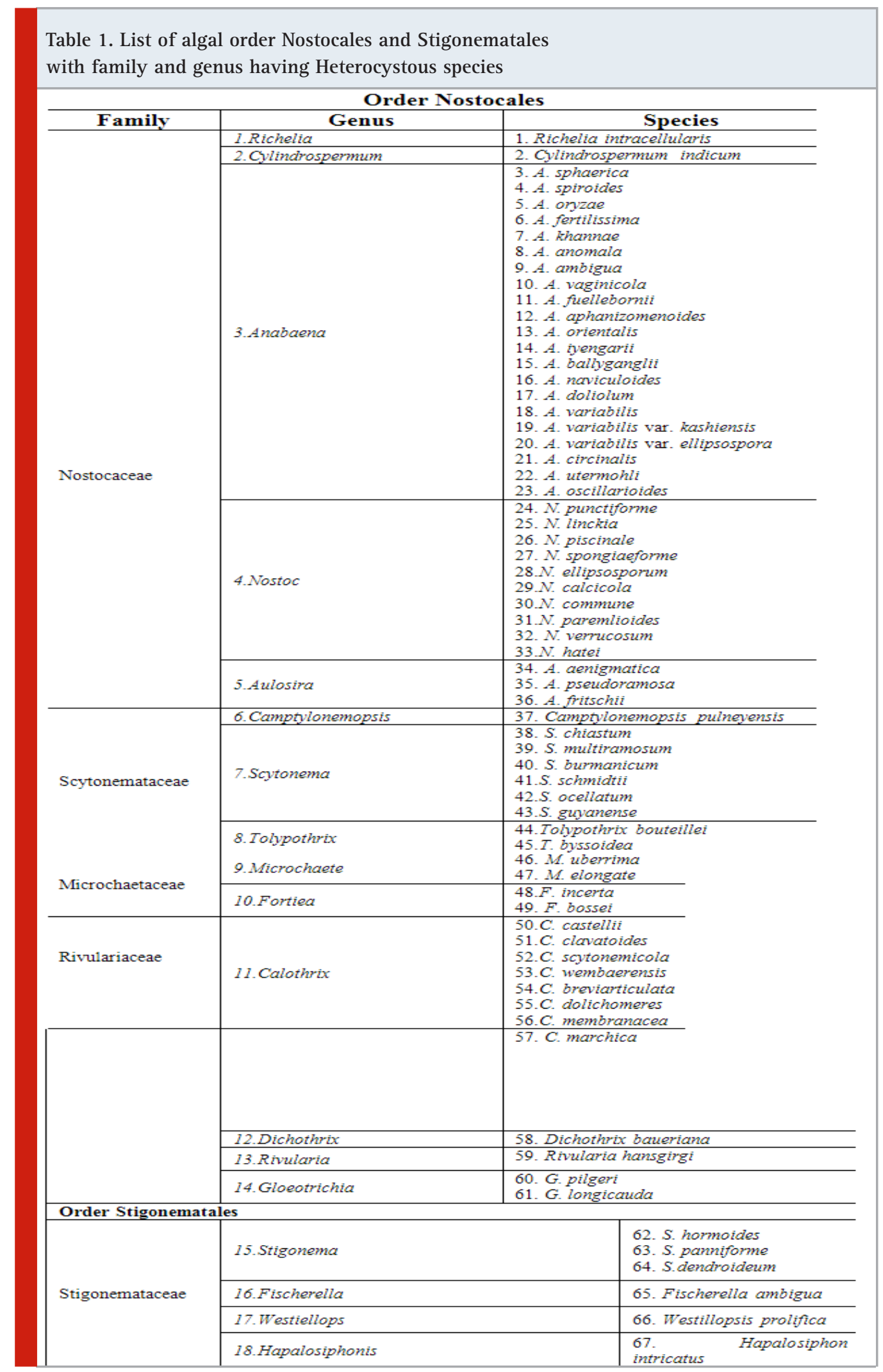

The identified Heterocystous blue green algae are structurally different in shape, size and structure. The identified blue green algal species of rice field are 67 in numbers withen 18 genus of two orders as Nostocales and Stigonematales. Order Nostocales consists 91.04\% of species and Order Stigonematales consists 8.95\% of 
species. Genus Anabaena having 31.34\% including 21 number of species, followed by genus Nostoc having $14.92 \%$ including 10 number of species. Other genus Calothrix11.94\%, Scytonema 8.95\% Aulosira and Stigonema 4.47\%, Tolypothrix, Microchaete, Fortiea, Gloeotrichia having 2.98\%, Richelia, Cylindrospermu $m$,Camptylonemopsis $1.49 \%$ among the (heterocystous) species found.

Algal species add readily available nutrition to crop plants in agricultural lands and ensure better crop nutrient management. They improve the texture of soil and increase the biochemical quality of the soil which forms a rapidly multiplying cover of microscopic plants. They have highly colonization with almost all types of soils. (Bold and Wanne,1978). The study shown that heterocystous Genus Anabaena having 31.34\% including 21 number of species in rice field of Mangaldai sub division. In another study "Taxonomic Enumeration of blue green algae of tea garden area of Mangaldoi sub division Darrang District Assam". Shown that the genus Anabaena (of heterocystous type) was the most dominant species throughout the study period. Blue green algae are sensitive to environmental change and mutrient fluctuation has been suggested by Frempong ( 1981); Tilman et al. (1982); Sudhkar et al. (1991). Herbicides have two fold effects on cropping they reduce the fertilizer need of crop which is the most efficient method for weed control, but such chemicals cause damage to the cyanobacterial photosynthesis either as photosynthetic indicator or as photosynthetic energy deviators (Dodge, 1975; Kapoor and Sarma, 1980); Kapoor et al., 1996a; Kapoor and Arora, 1996, 1998, 2000a, 2000b). According to Chopra (1971) $45.80 \%$ pesticidal compounds disappear from the soil within a year.

\section{CONCLUSION}

Among the heterocystous blue green algae genus Anabaena was the most dominant species throughout the study period. Blue green algae.

\section{REFERENCES}

APHA ( 2005) : Standard Methods for the Examination of Water and Waste Water. American Public Health Association, Washington, D. C.

Baruah, P. P. Kakati B. Ahmed .I (2009): Some fresh water algae of oil Refinery Effluent Drains of Assam India. Our Nature 7:139-134.

Bharadwaja, Y. (1933): Contribution to our knowledge of the Myxophyceae of India (Vol. 47).

Deka, M. and Bordoloi, R.P.M. (1991): Studies on the blue green algae from the rice fields of Assam. Phykos, 30: $173-180$.

Deka, Sheemanta Jyoti (2013): Taxonomic Studies of Blue Green Algae of Goalpara District, Assam. . A Ph. D Thesis, Gauhati University, Guwahati, Assam. Desikachary, T.V. (1959): Cyanophyta, Indian Council of Agricultural Research Publication, New Delhi, India. Press. London, pp.791.

Hazarika D , Duarah I Barukia J (2012) : An Ecological assessment of algal growth with particular reference to blue-green algae from upper Brahmaputra valley of Assam. Indian Journal of Fundamental and Applied Life Sciences ISSN: 2231-6345. Vol. 2 (3) July-September, pp.29-35

Moirangthem Thajamnbi (2020): Isolation and Characterization of Two Cyanobacterial Strains Calothrix Sp. and Microchaete Sp. from Rice Fields of Karimganj District, Assam, North East India. Current World Environment 11(2):399-405.

Sahu, J.K. (2000): Growth and nitrogen fixation of cyanobacteria from rice fields of Puri district, Orissa, Adv. Plant Sci., 13 (1): 47-50.

Tiwari, G.L. and Shukla, H. M. (1996): Growth of cyanobacteria in rice fields. First Intenet. Symp. Microb exploit., Banaras Hindu University,

Whitton, B. A. (2000).:Soils and rice fields. In: The Ecology of Cyanobacteria. (eds.) Whitton, B. A. and Potts, M., Kluwer Academic Publisher, Dordrecht. Netherland, pp. 233-255. 